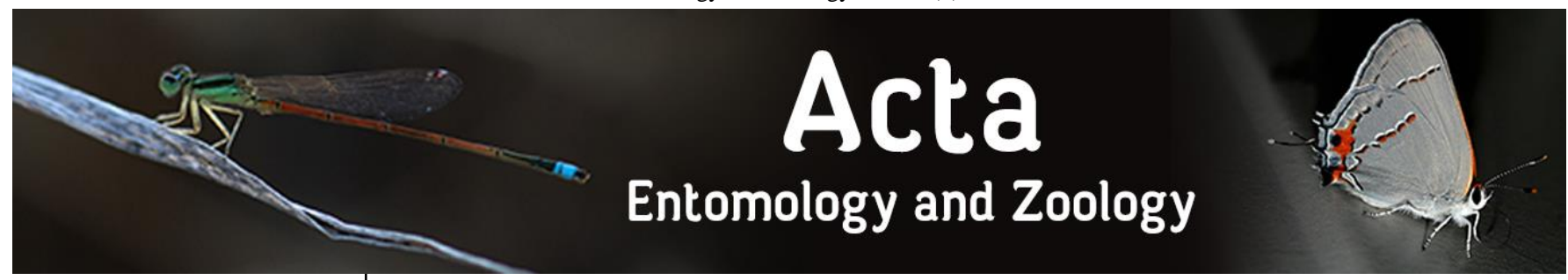

E-ISSN: 2708-0021 P-ISSN: 2708-0013 www.actajournal.com AEZ 2020; 1(2): 60-64 Received: 28-05-2020 Accepted: 03-07-2020

Abdul Samad Soomro IPM, Research Institute@ Quaid-e-Awam Agriculture Research Institute Larkana, Pakistan

Shabana Naz Mazari Entomology Department, SAU-SZABAC, Dokri, Campus of S.A.U, Tandojam, Pakistan

Abdul Sattar Soomro Post-Harvest Research, Institute, Rice Research Center, Dokri, Larkana Pakistan
Corresponding Author: Abdul Samad Soomro IPM, Research Institute @ Quaid-e-Awam Agriculture Research Institute Larkana, Pakistan

\section{Testing of Chrysoperla carnea (S) against Bimisia tabaci in Bt. cotton crop under field conditions}

\author{
Abdul Samad Soomro, Shabana Naz Mazari and Abdul Sattar Soomro
}

DOI: https://doi.org/10.33545/27080013.2020.v1.i2a.21

\section{Abstract}

The Green Lacewing, Chrysoperla carnea (Steph.) (Neuroptera: Chrysopidae) is a successful predatory insect; augmented for bio control practices especially for Integrated Pest Management. It is observed that green lacewing $C$. carnea (Steph.) has good potential of predation and caught good attention for its successful use against sucking insect pests. Currently it was evaluated for the management of white fly Bemisia tabaci infesting cotton crop. The data shown that the predator reduced white fly $B$. tabaci population significantly. Overall maximum population reduction was recorded in T-1 Chemical Control (6.01 $\pm 3.75 /$ leaf) followed by T-2 Bio-Control (green lacewing C. carnea) $(6.84 \pm 3.90 /$ leaf) as compare with control $(8.50 \pm 4.93 /$ leaf $)$ While maximum population of Whitefly $B$. tabaci $(10.40 \pm 5.75 /$ leaf) recorded in non Bt. Control (NIAB-78). Acetamaprid 20SL has good toxicity recoded minimum predatory population (0.04/plant) in T-1 (Chemical Control plot); maximum were observed (0.3/plant) in T2 Bio-Control (Green Lacewing C. carnea) released plot.

Keywords: Bt. cotton, bio-control, Chrysoperla carnea, Bimisia tabaci, management

\section{Introduction}

Cotton (Gossypium hirsutum L.) is widely preferred cash crop and being source of raw material for textile industry, importance is always on rise. Cotton accounts for $5.2 \%$ of value added in agriculture and $1 \%$ of Gross Domestic Product; GoP (2017). Practiced across the Punjab and Sindh provinces of Pakistan, but the Punjab province is lead $80 \%$ production comes from Punjab while $18 \%$ from Sindh province (Ali et al., 2013) ${ }^{[2]}$. Cotton is attacked by a variety of insect pests, out of which jassid, Amrasca devastans; whitefly, Bemisia tabaci; thrips, Thrips tabaci; spotted bollworm, Earias spp., pink bollworm, Pectinophora gosypiella and American bollworm, Helicoverpa armigera, are the most important Ahmed (1999) ${ }^{[1]}$. Different approaches are applied by the farmers to manage these insect pests. In this aspect different approaches are applied in different ways. This includes the cultivation of Bt. cotton. Bt. cotton was among the first genetically modified (GM) crops to be used in commercial agriculture. A gene from the soil bacterium Bacillus thuringiensis (Bt.) was transferred to the cotton genome. (Matthews and Tunstall, 1994) ${ }^{[17]}$ In USA and China, Bt cotton was commercialized in the mid1990s, and today the technology covers about 30-40 per cent of the cotton area in both countries. (Carpenter et al. 2002) ${ }^{[4]}$ transgenic plants have shown good results against targeted insect pests, but they are infested by the other insect pests such as sucking insects. Cotton whitefly $(\mathrm{B}$. tabaci) severely affect the economics of several cotton producing countries such as Pakistan due to direct damage by inhibition of photosynthetic activity and transmission of viral diseases to cotton that impairs the fiber quality (Ahmad, 1999) ${ }^{[1]}$. Natural enemies are a key component of IPM, and they are often recommended as the first line of defense in an IPM program (Lugojja et al., 2001) ${ }^{[9]}$. Chrysoperla carnea, one of the most important natural enemies has a great role in reducing the use of pesticides and environmental pollution in field crops and vegetables (Dean and Sterling, 1992) ${ }^{[6]}$ Biological control by the use of predator $C$. carnea has also gained importance for pest management in Pakistan. Some recent studies provide a crucial example of release sites for lacewings against Bemisia tabaci (Genn.) in cotton (Zia et al., 2008) ${ }^{[16]}$. The larval stage are more voracious feeder of soft bodied insect such as aphid, whitefly, mealy bugs, thrips, mites, leaf hoppers, jassids, caterpillar and insect eggs (Ulhaq et al., 2006 and Sarwar and Salman, 2016) ${ }^{[14,13]}$. In present study green lacewing, $C$. carnea a general predator evaluated as biological control agent in Bt. Cotton crop against the white fly ( $B$. tabaci) insect one of the most important and heavy damaging sucking insect reported in Cotton under field conditions. 


\section{Materials and Methods}

The research was conceded to appraise Chrysoperla cornea for the management of Whitefly Bemisia tabaci in BtCotton crop under field conditions. Comparative population development of whitefly (B. tabaci) were recorded in NIAB-78 and Bt cotton.

The crop was sown in the month of $2^{\text {nd }}$ week of April at farmer's field near Sindh Agriculture University, Tandojam. Sowing was done by dibbling method on ridges. All the inputs like fertilizer and irrigation were applied accordingly with recommended dosage.

The experiment was design with RCBD with four replications and four treatments;

\begin{tabular}{|c|c|c|c|}
\hline Treatment & Control Measure & Product & Dose \\
\hline 01 & Chemical Control & Acetamaprid 20 SL & 200ml/Acre \\
\hline 02 & Biological Control & Chrysoperla carnea & 250-300 eggs/Card(15Cards/Acre) \\
\hline 03 & Natural & Check Bt & - \\
\hline 04 & Natural & Check Non Bt (NIAB-78) & \\
\hline
\end{tabular}

The Chrysoperla carnea cards were acquired from Biological control laboratory, Nuclear Institute of Agriculture (NIA) Tandojam, Pakistan. The predators were released in the field at fortnight interval. The $1^{\text {st }}$ application of predatory cards were practiced after 40 days of sowing, the cards were fixed below the leaves with stapler preferably on central leaves at the center of treated plots.

Efficiency of $C$. carnea was compared with Acetamaprid 20 SL, one of the most popular insecticides widely used for the control of whitefly B. tabaci insect pests by the farmers. The treatments were applied at fortnightly interval. Pre-treatment data were recorded 24 hours before application and post treatment data were taken after three and seven days of application of treatments. The data were recorded by selecting five plants at random from each treatment. From each plant five leaves were observed for recording the population of sucking insects i.e., one from top, 2 from middle and 2 from bottom portion of plant and whole plant was observed for recording predator population. Predatory population was recorded per plant, 20 plants were selected from each Treatment for collecting the data. Finally Data was analyzed through statistical procedure.

\section{Results}

\subsection{Whitefly, Bemisia tabaci (Genn.)}

Whitefly Bemisia tabaci (Genn.) appeared on cotton crop from $1^{\text {st }}$ week of June and remained till the last week of November. Initial population was recorded in NIAB-78 plots, while Bt infestation was recorded soon after. The maximum whitefly population in Chemical Control treated plots were (12.35/leaf) on $31^{\text {st }}$ July, in Bio-Control plots (13.65/leaf) observed on $31^{\text {st }}$ July, T-3 was Bt. Control and (15.21/leaf) population of whit fly recorded on $03^{\text {rd }}$ August, (17.51/leaf) population was observed in NIAB (non Bt.) Control on $31^{\text {st }}$ July. It was recorded that population was at its peak in the last week of July and $1^{\text {st }}$ week of August. Maximum infestation was recorded in non Bt. Control. Overall Average Mean shown that the minimum population was recorded in T-1 Chemical treatment (6.01/leaf) followed by T-2 Bio-Control (Chrysoperla carnea natural enemy) (6.84/leaf) as compared with Control, where population recorded average (8.5/leaf) while non Bt. Control (NIAB-78) treatment average population was highest among all treated plots observed (10.40/leaf). The analysis showed that there was significantly $(P<0.05)$ different from each other. The results are presented in table $\mathrm{I}$ to $\mathrm{V}$

Table 1: Mean Population of Whitefly, Bemisia tabaci (Genn.) in different treatments on cotton crop under field conditions

\begin{tabular}{|c|c|c|c|c|c|}
\hline \multicolumn{7}{|c|}{ Mean population of whitefly/leaf } \\
\hline Observation Date & T1 & T2 & T3 & T4 & Mean \\
\hline $01-06-16$ & 0 & 0 & 0 & 0 & 0.1 \\
\hline $04-06-16$ & 0 & 0.1 & 0 & 0.5 & 0.23 \\
\hline $07-07-16$ & 0.21 & 0.21 & 0 & 5.22 & 5.4325 \\
\hline $15-06-16$ & 5.77 & 5.51 & 5.23 & 5.11 & 4.855 \\
\hline $18-06-16$ & 3.26 & 5.56 & 5.49 & 6.38 & 5.3075 \\
\hline $22-06-16$ & 4.17 & 4.28 & 6.4 & 6.27 & 6.005 \\
\hline $30-06-16$ & 5.39 & 6.17 & 6.19 & 6.18 & 4.8425 \\
\hline $03-07-16$ & 3.1 & 4.9 & 5.19 & 6.46 & 5.115 \\
\hline $07-07-16$ & 4.24 & 4.46 & 5.3 & 16.23 & 13.6025 \\
\hline $15-07-16$ & 12.3 & 12.45 & 13.43 & 16.63 & 12.4275 \\
\hline $18-07-16$ & 9.28 & 12.27 & 11.53 & 16.44 & 12.2375 \\
\hline $22-07-16$ & 10.08 & 9.9 & 12.53 & 17.51 & 14.0325 \\
\hline $31-07-16$ & 12.35 & 13.65 & 12.62 & 17.32 & 13.1175 \\
\hline $03-08-16$ & 7.4 & 12.54 & 15.21 & 16.5 & 12.335 \\
\hline $07-08-16$ & 9.33 & 9.51 & 14 & 15.97 & 13.2875 \\
\hline $15-08-16$ & 11.34 & 10.7 & 15.14 & 14.17 & 11.7025 \\
\hline $19-08-16$ & 8.14 & 9.3 & 15.2 & 14.66 & 10.5375 \\
\hline $23-08-16$ & 7.1 & 7.23 & 13.16 & 13.08 & 10.8225 \\
\hline $30-08-16$ & 10.05 & 8.07 & 12.09 & 11.66 & 8.78 \\
\hline $02-09-16$ & 6.1 & 7.25 & 10.11 & 10.11 & 7.165 \\
\hline $06-09-16$ & 4.12 & 6.11 & 8.32 & 12.22 & 7.0925 \\
\hline $15-09-16$ & 4.77 & 5.51 & 5.87 & 11.11 & 5.855 \\
\hline $18-09-16$ & 2.26 & 4.56 & 5.49 & 9.9 & 5.75 \\
\hline $22-09-16$ & 3.5 & 4.1 & 5.5 & $10.40 \pm 5.72$ & $7.94 \pm 4.58$ \\
\hline Mean SD & $6.01 \pm 3.75$ & $6.84 \pm 3.90$ & $8.50 \pm 4.93$ & & \\
\hline
\end{tabular}

Means followed by significantly $(P<0.05)$ different from each other 
Table 2: Mean Population of Whitefly, Bemisia tabaci (Genn.) on cotton crop under field conditions.

\begin{tabular}{|c|c|c|c|c|c|c|c|c|c|c|c|c|}
\hline \multirow{3}{*}{ Application } & \multicolumn{12}{|c|}{ Mean population of green lacewing/plant } \\
\hline & \multicolumn{4}{|c|}{ Pre Treatment } & \multicolumn{4}{|c|}{ Post Treatment 3D } & \multicolumn{4}{|c|}{ Post Treatment 7D } \\
\hline & T1 & $\mathbf{T 2}$ & T3 & T4 & T1 & T2 & T3 & T4 & T1 & T2 & T3 & T4 \\
\hline 01 & 5.77 & 5.51 & 5.23 & 5.22 & 3.26 & 5.56 & 5.49 & 5.11 & 4.17 & 4.28 & 6.40 & 6.38 \\
\hline 02 & 5.39 & 6.17 & 6.19 & 6.27 & 3.10 & 4.90 & 5.19 & 6.18 & 4.24 & 4.46 & 5.30 & 6.46 \\
\hline 03 & 12.30 & 12.45 & 13.43 & 16.23 & 7.10 & 7.23 & 13.16 & 14.66 & 9.33 & 9.51 & 14.00 & 16.50 \\
\hline 04 & 11.34 & 10.7 & 15.14 & 15.97 & 8.14 & 9.30 & 15.20 & 14.17 & 7.10 & 7.23 & 13.16 & 14.66 \\
\hline 05 & 10.05 & 8.07 & 12.09 & 13.08 & 6.10 & 7.25 & 10.11 & 11.66 & 7.10 & 7.23 & 13.16 & 14.66 \\
\hline 06 & 10.05 & 8.07 & 12.09 & 13.08 & 6.10 & 7.25 & 10.11 & 11.66 & 4.12 & 6.11 & 08.32 & 10.11 \\
\hline 07 & 4.77 & 5.51 & 5.87 & 12.22 & 2.26 & 4.56 & 5.49 & 11.11 & 3.50 & 4.10 & 5.50 & 9.90 \\
\hline Mean & 8.52 & 8.06 & 10.0 & 11.7 & 5.15 & 6.57 & 9.25 & 10.6 & 5.65 & 6.13 & 9.40 & 11.2 \\
\hline
\end{tabular}

Table 3: Comparative Control Percentage difference between Chemical and Bio-Control

\begin{tabular}{|c|c|c|c|}
\hline Application & Observation & Chemical & C. carnea \\
\hline \multirow{3}{*}{$1^{\text {st }}$} & Pre-Treatment & -10.32 & -5.35 \\
\cline { 2 - 4 } & Post-Treatment 3D & 40.6193 & -1.27 \\
\cline { 2 - 4 } & Post-Treatment 7D & 34.84 & 33.12 \\
\hline \multirow{3}{*}{$2^{\text {nd }}$} & Pre-Treatment & 12.92 & 0.32 \\
\cline { 2 - 4 } & Post-Treatment 3D & 40.26 & 5.58 \\
\cline { 2 - 4 } & Post-Treatment 7D & 20.00 & 15.84 \\
\hline \multirow{3}{*}{$3^{\text {rd }}$} & Pre-Treatment & 8.41 & 7.29 \\
\cline { 2 - 4 } & Post-Treatment 3D & 19.51 & -6.418 \\
\cline { 2 - 4 } & Post-Treatment 7D & 19.55 & 20.98 \\
\hline \multirow{4}{*}{$4^{\text {th }}$} & Pre-Treatment & 2.13 & -8.16 \\
\cline { 2 - 4 } & Post-Treatment 3D & 51.34 & 17.55 \\
\cline { 2 - 4 } & Post-Treatment 7D & 33.35 & 32.07 \\
\hline \multirow{3}{*}{$5^{\text {th }}$} & Pre-Treatment & 25.09 & 29.32 \\
\cline { 2 - 4 } & Post-Treatment 3D & 46.44 & 38.81 \\
\cline { 2 - 4 } & Post-Treatment 7D & 46.04 & 45.06 \\
\hline \multirow{3}{*}{$6^{\text {th }}$} & Pre-Treatment & 16.87 & 33.25 \\
\cline { 2 - 4 } & Post-Treatment 3D & 39.66 & 28.28 \\
\cline { 2 - 4 } & Post-Treatment 7D & 50.48 & 26.56 \\
\hline \multirow{3}{*}{$7^{\text {th }}$} & Pre-Treatment & 18.73 & 6.13 \\
\cline { 2 - 4 } & Post-Treatment 3D & 58.83 & 16.93 \\
\cline { 2 - 4 } & Post-Treatment 7D & 36.36 & 25.45 \\
\hline
\end{tabular}

\subsection{Green lacewing, Chrysoperla carnea (Steph.)}

Green lacewing Chrysoperla carnea (Steph.) is an important predator of aphid as well as for other sucking insects like whitefly, thrips and jassid and certain mites. It is commonly known as aphid lion. The eggs were released in the experimental field. The C. carnea larval population was recorded from the $2^{\text {nd }}$ week of June till the last week of September when the $1^{\text {st }}$ picking was taken, their maximum activities were recoded during $1^{\text {st }}$ week of August. The maximum population $(0.85 /$ plant) was recorded in $\mathrm{T} 1$ in which natural enemies (C. carnea cards) were released as a pest management option (Table-IV) the minimum population (0.05/plant) was recorded in the various treatments T2, T3 and T4 (Confidor treatment), (B.T. control) and (NIAB-78) plots respectively. The over all mean population of $C$. carnea shown in (Table-1V) indicated that the maximum $C$. carnea population was recorded (0.3/plant) in T2 (C. carnea natural enemies) plot, whereas the minimum population was recorded as (0.04/plant) in T1 (Acetamaprid $20 \mathrm{SL}$ insecticide) plot. The analysis of data showed that there was not significant $(P<0.05)$ difference in population development of $C$. carnea on different treatments.

Table 4: Mean Population of green lacewing, Chrysoperla carnea (Steph.) in different treatments on cotton crop under field conditions.

\begin{tabular}{|c|c|c|c|c|c|}
\hline \multicolumn{7}{|c|}{ Mean population of green lacewing/plant } \\
\hline Observation Date & T1 & T2 & T3 & T4 & Mean \\
\hline $01-06-16$ & 0 & 0 & 0 & 0 & 0 \\
\hline $04-06-16$ & 0 & 0 & 0 & 0 & 0 \\
\hline $07-07-16$ & 0 & 0 & 0 & 0 & 0 \\
\hline $15-06-16$ & 0.1 & 0.55 & 0.25 & 0.2 & 0.275 \\
\hline $18-06-16$ & 0.05 & 0.85 & 0.15 & 0.15 & 0.3 \\
\hline $22-06-16$ & 0.1 & 0.5 & 0.2 & 0.2 & 0.25 \\
\hline $30-06-16$ & 0.1 & 0.35 & 0.1 & 0.15 & 0.175 \\
\hline $03-07-16$ & 0.05 & 0.55 & 0.15 & 0.2 & 0.2375 \\
\hline $07-07-16$ & 0.05 & 0.45 & 0.1 & 0.15 & 0.1875 \\
\hline $15-07-16$ & 0.05 & 0.35 & 0.1 & 0.15 & 0.1625 \\
\hline $18-07-16$ & 0.1 & 0.3 & 0.15 & 0.05 & 0.15 \\
\hline $22-07-16$ & 0.05 & 0.4 & 0.15 & 0.25 & 0.2125 \\
\hline $31-07-16$ & 0.05 & 0.35 & 0.15 & 0.2 & 0.1875 \\
\hline $03-08-16$ & 0 & 0.35 & 0.2 & 0.25 & 0.2 \\
\hline $07-08-16$ & 0 & 0.55 & 0.2 & 0.2 & 0.2375 \\
\hline $15-08-16$ & 0 & 0.15 & 0.05 & 0.05 & 0.0625 \\
\hline $19-08-16$ & 0.05 & 0.15 & 0.1 & 0.05 & 0.0875 \\
\hline $23-08-16$ & 0.05 & 0.35 & 0.05 & 0 & 0.1125 \\
\hline $30-08-16$ & 0 & 0.25 & 0 & 0.05 & 0.075 \\
\hline $02-09-16$ & 0.05 & 0.3 & 0 & 0.05 & 0.1 \\
\hline $06-09-16$ & 0.06 & 0.39 & 0.13 & 0.1 & 0.17 \\
\hline $15-09-16$ & 0 & 0.25 & 0 & 0.05 & 0.075 \\
\hline $18-09-16$ & 0.05 & 0.3 & 0 & 0.1 & 0.1125 \\
\hline $22-09-16$ & 0.05 & 0.25 & 0 & 0.05 & 0.0875 \\
\hline MEAN & 0.04 & 0.3 & 0.092917 & 0.110417 & 0.13583 \\
\hline
\end{tabular}


\begin{tabular}{l|l|l|l|l|l|} 
SD & 0.03 & 0.19 & 0.080675 & 0.083379 & 0.08338
\end{tabular}

* Means followed are not significantly $(P<0.05)$ different from each other by LSD.

Table 5: Mean Population of green lacewing, Chrysoperla carnea (Steph.) after release of predator on cotton crop under field conditions.

\begin{tabular}{|c|c|c|c|c|c|c|c|c|c|c|c|c|}
\hline \multirow{3}{*}{ Application } & \multicolumn{10}{|c|}{ Mean population of green lacewing/plant } \\
\cline { 2 - 14 } & \multicolumn{3}{|c|}{ Pre Treatment } & \multicolumn{3}{c|}{ Post Treatment 3D } & \multicolumn{3}{c|}{ Post Treatment 7D } \\
\cline { 2 - 14 } & T1 & T2 & T3 & T4 & T1 & T2 & T3 & T4 & T1 & T2 & T3 & T4 \\
\hline 01 & 0.25 & 0.30 & 0.20 & 0.15 & 0.05 & 0.55 & 0.10 & 0.25 & 0.10 & 0.40 & 0.20 & 0.10 \\
\hline 02 & 0.10 & 0.55 & 0.25 & 0.20 & 0.05 & 0.85 & 0.15 & 0.15 & 0.10 & 0.50 & 0.20 & 0.20 \\
\hline 03 & 0.10 & 0.45 & 0.10 & 0.15 & 0.05 & 0.45 & 0.15 & 0.20 & 0.05 & 0.45 & 0.10 & 0.15 \\
\hline 04 & 0.01 & 0.30 & 0.15 & 0.20 & 0.05 & 0.40 & 0.15 & 0.15 & 0.05 & 0.35 & 0.15 & 0.20 \\
\hline 05 & 0.00 & 0.35 & 0.20 & 0.25 & 0.00 & 0.55 & 0.20 & 0.20 & 0.00 & 0.15 & 0.05 & 0.05 \\
\hline 06 & 0.05 & 0.15 & 0.10 & 0.05 & 0.05 & 0.35 & 0.00 & 0.05 & 0.00 & 0.25 & 0.00 & 0.05 \\
\hline Mean & 0.10 & 0.35 & 0.16 & 0.16 & 0.04 & 0.52 & 0.12 & 0.16 & 0.05 & 0.35 & 0.11 & 0.12 \\
\hline
\end{tabular}

\section{Discussion}

In present study different management options were tested on Bt- cotton against most damaging sucking insect pest. Release of Chrysoperla carnea cards in cotton for reduction of population of white fly was compared with control. Whitefly population was lower in Bt-cotton control compared to NIAB-78 control. Pest infestation was recorded continuous after its appearance.

However, in Chemical Control; Whitefly population was significantly lower than Bt-control. Results further indicate that Acetamaprid (20SL) was toxic to $C$. carnea and lowest population of $C$. carnea was recorded in Acetamaprid (20SL) applied treatment. Ameta and Sharma (2005) [3] recorded reduction in population of A. gossypii, A. biguttula and T. tabacci after application of Insecticide. Chaudhary et al. (2005) ${ }^{[5]}$ also reported that confidor was superior than Clothianidia in controlling the aphid and jassid populations in cotton.

Saleh el al., (2017) ${ }^{[14]}$ studied that Chrysoperla carnea is a major predator of some white fly, aphid and thrips. Mansoor-ul-Hasanv (2015) experiment results shown that integration of bio control agents such as Chrysoperla carnea proved as effective as chemical control using recommended insecticides against sucking insect pests.

Hamid et al. (2020) released the larvae of Chrysoperla carnea against whitefly in a greenhouse. Adult, eggs and nymph of Bemisia tabaci were affected by $C$. carnea. Overall mean population of whitefly indicated positive correlation with the number of larvae introduced.

Hanumantharaya and Naik (2007) ${ }^{[8]}$ studied the release of Chrysoperla carnea grubs at 0.75 and 1.0 lakhs/ha. Starting from 43 DAS reduced the sucking pest (leaf hoppers, thrips, aphids and whiteflies) and bollworm $H$. armigera and increased the seed cotton yield. Wadhawa and Gill (2007) studied the biodiversity of natural enemies on $\mathrm{Bt}$ and non-Bt cotton hybrids and found that $\mathrm{Bt}$ cotton hybrid recorded higher population of Chrysoperla carnea spiders, Geocoris bug, and yellow wasps. Manju et al. (2007) ${ }^{[10]}$ investigated the effect of Bt- cotton fed aphids on the feeding potential and development of $C$. carnea and reported no variation in the feeding potential and development period of larvae of $C$. carnea fed on aphids feeding on $\mathrm{Bt}$ and non $\mathrm{Bt}$ cotton plants. They recorded significantly higher number of natural enemies on $\mathrm{Bt}$ - Cotton compared with non Bt- cotton.

\section{Conclusion}

Both the treatments (Chrysoperla carnea and Acetamaprid 20SL) suppressed the whitefly population. The Acetamaprid (20SL) was toxic to C. carnea (predator); lowest population was recorded in chemical control plot.

\section{Acknowledgment}

The authors are grateful to the necessary support given by Abdul Latif Joyo Principal Scientist IMP Research Institute, Larkana, Muzafar Ali Soomro Principal Scientist/ Entomologist @ Rice Research Center Dokri, Larkana, Pakistan.

\section{References}

1. Ahmad Z. Insecticides Resistance Management in Cotton. Proc. ICAC-CCRI, Multan, Pakistan 1999, 5-20.

2. Ali H, Ali H, Faridi Z, Ali H. Production and forecasting trends of cotton in Pakistan: An analytical view, J Basic. Appl. Sci. Res 2013;3(12):97-101.

3. Ameta OP, Sharma KC. Bioefficacy of imidacloprid (Confidor) against sucking insect pests of cotton. Insect Environment 2005;11(1):66-70.

4. Carpenter J, Felsot A, Goode T, Hammig M, Onstad D, Zankula S. Comparative Environmental Impacts of Biotechnology- derived and Traditional Soybean, Corn, and Cotton Crops, Ames: Council for Agricultural Science and Technology 2002.

5. Choudhary RK, Tomar SPS, Shrivastava VK, Yadav AS. Studies on field evaluation of imidacloprid Confidor 17.8 SL) against sucking pests of cotton in rainfed condition. Journal of Cotton Research and Development 2005;19(2):241-243.

6. Dean DA, Sterling WL. Comparison of sampling methods to predict phenology of predaceous Arthopods in a cotton Agro-ecosystem. Text Agriculture Experiment Station Miscellaneous publication 1992, 931.

7. Govt. of Pakistan, Economic Survey of Pakistan, Federal Bureau of Statistics, Islamabad, Pakistan 2017.

8. Hanumantharaya L, Goud KB, Naik LK. Use of green lacewing, Chrysoperla carnea (Stephens) and neem seed kernel extract for management of insect pests on cotton. Karnataka Journal of Agricultural Sciences 2008;21(1):41-44.

9. Lugojja F, Ogenga-Latigo MW, Smit JM. Impact of defoliation on the agronomic performance of sweet potato in Uganda. Journal of African Crop Science 2001;9:103.

10. Manju AC, Patil BV, Bheemanna M, Hosamani AC, Hanchinal SG, Bansi AB. Influence of Bt cotton fed aphids on the feeding potential and development of Chrysoperla carnea (Stephens). Cotton Research and Development 2007;21(1):118-119.

11. Hira Shahjahan, Javed Khan, Ahmad-Ur-Rahman Saljoqi, Ehsan Ul Haq, Hussain Shah, Imtiaz Khan, et al. Biological parameters and feeding efficiency of 
Chrysoperla Carneastephens (Neuroptera: Chrysopidae) feed on Citrus mealy bug Planococcus Citri (Risso) (Hemiptera: Pseudococcidae) under controlled conditions. Int. J Agric. Extension Social Dev. 2020;3(1):46-51.

12. Moseley WG, Gray LC. (eds). Hanging by a Thread: Cotton, Globalization and poverty in Africa. Athens OH: Ohio University Press and Nordic Africa Press 2008. ISBN 978-0-89680- 260-5

13. Sarwar M, Salman M. From Production to Field Application Methodology of Generalist Predator Green Lacewing, Chrysoperla carnea [Stephens] (Neuroptera: Chrysopidae). International Journal of Zoology Research 2016;1(1):35-40.

14. Ulhaq MM, Sattar A, Salihah Z, Farid A, Usman A, Khattak SUK. Effect of different artificial diet on the biology of adult green lacewing (Chrysoperla carnea: Stephens.). Songklanakarin J Sci Technol 2006;28(1):18.

15. Wadhwa S, Gill RS. Effect of Bt-cotton on biodiversity of natural enemies. Journal of Biological Control. 200s 7;21(1):9-16.

16. Zia K, Hafeez F, Khan RR, Arshad M, Ullah UN. Effectiveness of Chrysoperla carnea (Stephens) (Neuroptera: Chrysopidae) on the population of Bemisia tabaci (Genn.) (Homoptera: Aleyrodidae) in different cotton genotypes. Journal of Agricultural and Social Sciences 2008;4:112-116.

17. Matthews GA, Tunstall JP. (Eds.). Insect Pests of Cotton. Published by CAB International Wallingford U.K, 1994. 